\title{
Epidemiology of Use of a Traditional Spirit "Sodabi" in the General Population of Togo
}

\author{
Tagba Pelei \\ Laboratory of Biochemistry/Nutrition, \\ Faculty of Science, University of Lomé, Lomé-Togo \\ Osseyi G. Elolo \\ Advanced School of Biological and Food Technologies (ESTBA); \\ Department of Food Science and Food Technology, \\ University of Lomé, Lomé-Togo \\ Lamboni Raphael Courdjo \\ Laboratory of Biochemistry/Nutrition, \\ Faculty of Science, University of Lomé, Lomé-Togo
}

doi: 10.19044/esj.2016.v12n27p177 URL:http://dx.doi.org/10.19044/esj.2016.v12n27p177

\begin{abstract}
The purpose of this paper is to evaluate the profile of sodabi consumption in the Togolese population. This transverse descriptive study was conducted over a nine month period from June 9, 2013 to March 9, 2014, throughout the five regions of Togo. Findings demonstrated a clear profile of 2388 sodabi drinkers. $1672(70.02 \%)$ men and $716(29.98 \%)$ women. Prevalence was $62.45 \%$ in the population studied. Mean age was 35.3 years. Almost all subjects interrogated (98.48\%) were togolese nationals. The study included the following ethnic and regional groups, the Kabyè-Tem ethnic group (43.59\%) and the Paragourma-Akan groups $(23.50 \%)$ were the most represented among the subjects interrogated. More than a third $(25.67 \%)$ of subjects interviewed was unemployed with a higher unemployment rate in the Maritime region and Lomé Commune (37.16\%). Most of the people interrogated (49.66\%) were living as couples (married or cohabiting). $4.06 \%$ of subjects drank sodabi only. $51.40 \%$ of drinkers abused sodabi ( $40.59 \%$ men against $10.81 \%$ women). The prevalence of noxious alcohol use was high $(12.35 \%)$ among unemployed participants. $25.51 \%$ of drinkers visited drinking establishments once a week and $22.10 \%$ almost every day. The euphoric effect of alcohol (45.23\%) and friendly atmosphere (19.39\%) of the drinking establishment were the main reasons for attendance (64.62\%). Of the damage caused by the abuse of sodabi, $39.26 \%$ of subjects showed somatic or neurological complications and $60.74 \%$ psychological and psychiatric complications. Updating these data seems necessary, because
\end{abstract}


combating excessive drinking is one of the main objectives of current togolese public health policy.

Keywords: Sodabi, Consumption, Social determinants, Togo

\section{Introduction}

The use of craft alcoholic beverages has been an integral part of many cultures and civilizations (McGovern, 2009). There are many places in the world today where versions of these traditional patterns originating in tribal and rural societies persist (Willis, 2006). In the West African region, and in Togo particularly, is produced by the fermentation of oil palm sap (Elaeis guineensis), a spirit, called "Sodabi" whose conditions of production and sale, quality, and quantities produced and consumed are beyond control. Formerly confined to rural areas and to adults on festive occasions, traditional ceremonies and preparation of medicinal maceration, sodabi today has gained young adepts and broken into urban areas with a proliferation of drinking establishments called "white curtains." Economic problems have kept imported spirits out of reach of the most disadvantaged social strata. The latter have resorted to sodabi which is less expensive. This is why drinking establishments and sales outlets are always filled with drinkers. They are visited at all times of the day or night by consumers of all ages. In imitation of a new form of whisky packaged in small sachets, it has recently appeared on the Togolese market, small bags of colored and flavored sodabi at a price of $100 \mathrm{FCFA}(€ 0.15)$ putting this product within reach of minors and schoolchildren. The sale of sodabi became a flourishing trade for producers and retailers and consumption is now for many young and old a way of life, a refuge from everyday problems causing massive and ambient alcoholism. In 2010, the prevalence of alcohol dependence in Togo was estimated at $3.3 \%$ while that of the African sub-region was $1.4 \%$ (WHO, 2014). Consumers at risk were assessed at $12.0 \%$ for men and $9.9 \%$ among women (Agoudavi et al., 2015). This pernicious "democratization" of sodabi consumption has not taken place without serious social consequences. The harmful use of alcohol ranks among the top five risk factors for disease, disability and death throughout the world (WHO, 2010; Lim et al., 2012). It is a causal factor in more than 200 disease and injury conditions (WHO, 1992), the harmful use of alcohol thus accounts for $5.9 \%$ of all deaths worldwide. One study, for example, found that alcohol was the cause of $11.47 \%$ of hypertension cases in rural Togo (Goeh-Akue et al., 2008). It therefore appears necessary to identify the profile of consumers in order to conceive of appropriate measures to contain the tendency toward the excessive consumption of sodabi. 
This research was initiated to determine the contribution of sodabi to ambient alcoholism in Togo, and to gather new data, factual indicators allowing control programs against the risk factors for non-communicable diseases, and to develop adequate control policies and strategies.

\section{Methods}

- Mode of investigation: This is an epidemiological study using the AUDIT questionnaire to define the profile of consumers of sodabi, a traditional spirit produced in Togo. This survey was conducted between June 9, 2013 and 9 March 2014 and included a representative sample of the population of Togo. Togo is a low-income country (GDP per capita: US \$ 1400). It is located in West Africa and has an area of $56000 \mathrm{~km}^{2}$ and a population of approximately 6,306,000 inhabitants. The majority of the people are older than 15 years (58\%) (Agoudavi et al., 2015).

- Selection criteria: The investigations were conducted nationally with adults of both genders in five regions of the country. The tested subjects lived in urban and rural areas within the sampled area for at least 6 months and were between 15 and 64 years of age at the time of the investigation. They were recruited after obtaining their informed consent to participate in the study. Individuals who could not answer the recruitment questions were not included

- Sampling: The sample size of 4,300 individuals per age group and sex were selected following Schwartz's formula (1969) and the recommendations outlined in the STEPS manual in part 2, Section 2. Taking into consideration our target sample of people between 15 and 64 years of age, it was found that the number required per age group and per sex was 10 . This gave a provisional size of 3820 people as the minimum number of individuals necessary for the study. Taking into consideration previous investigations in the field of health in Togo (with an estimated non-response rate of $10 \%$ ), the definitive size of the retained sample size was 4300 individuals.

- Data collection: The objective was to screen the three sodabi consumption patterns: risky, harmful and alcohol dependence in the Togolese population. The questionnaire used is a self-questionnaire to be filled by the respondent at home, drinking establishment or in hospital during a consultation. It includes questions about socio-demographic and alcohol data found in the AUDIT (Alcohol Use Disorders Identification Test) questionnaire. The AUDIT questionnaire was developed by the WHO (Gache et al., 2005) to screen for risky, harmful or massive alcohol consumption habits. It includes 10 questions covering the three categories of alcohol consumption. General practitioners, medical school students, laboratory assistants and managers of drinking establishments and sodabi 
outlets in the regions of Togo were solicited and trained to carry out this investigation. They were selected on a voluntary basis, after a telephone or email contact or after appointment with a doctor or physicians. This questionnaire is delivered with an explanatory letter guaranteeing the anonymity of the respondent. It is specified that the subject can be assisted by a third person especially if he or she is illiterate.

- Statistical analyses: The results are presented as mean \pm standard deviation of the mean. Statistical analyses were performed using Excel software. When two groups were compared, the statistical differences were determined by the nonparametric Mann-Whitney test. Beyond two groups, statistical differences were determined by Kruskal-Wallis one-way analysis of variance followed by Fischer LSD test. The value of $p=0.05$ is set as the significance limit.

\section{Results and Discussion \\ Socio- demographic characteristics}

The results of this cross-sectional study highlights the prevalence of sodabi

consumption in Togo. Of the 2388 drinkers, 1672 are men (70.02\%) against 716 women $(29.98 \%)$ or a consumption prevalence of $62.45 \%$ nationally. The sample was young, with a mean age of $35.3 \pm 11.87$ years, this value is comparable to the mean age of $34.01 \pm 12.65$ years reported by Agoudavi et al., (2015). Almost all (98.48\%) of the respondents were of Togolese nationality with the Kabyè-Tem (43.59\%) and Para-gourma-Akan $(23.50 \%)$ ethnic groups dominant. In the study population, the 25-34 age group was the most represented with a rate of $38.84 \%$, including $70.93 \%$ men and $29.07 \%$ women. This same observation was made during the STEPS TOGO 2010 investigation in which the 25-34 age group was most represented in a proportion of $29.4 \%$. A predominance of males was noted in all age groups. In an epidemiological inquiry about the users of traditional drinking establishments, conducted by Yeo-Tenena et al., (2006) on alcohol consumption, all interviewees were male because women encountered in the study areas had refused to take part in the survey. The over 64 age group was the least represented with $1.26 \%$. Similarly, the 55-64 age group was the least represented with $8.4 \%$ in the STEPS survey TOGO (2010). The unemployed accounted for $25.67 \%$ of drinkers with higher rates in the Maritime Region and Lomé Commune (37.16\%), followed by the Kara Region (32.42\%). Farmers follow with $19.82 \%$ (46.70\% in the Plateau Region). Artisans, merchants and entrepreneurs come third with $17.58 \%$. Intermediate professions were less represented with $3.83 \%$ (Table 1). 
Table 1: Socio-demographic parameters of the survey

\begin{tabular}{|c|c|c|c|c|c|c|c|c|c|c|}
\hline & \multicolumn{2}{|c|}{ RS } & \multicolumn{2}{|c|}{ RK } & \multicolumn{2}{|l|}{$\mathrm{RC}$} & \multicolumn{2}{|c|}{ RP } & \multicolumn{2}{|c|}{ RM-L } \\
\hline & Effective & $\%$ & Effective & $\%$ & Effective & $\%$ & Effective & $\%$ & Effective & $\%$ \\
\hline \multicolumn{11}{|l|}{ Sex } \\
\hline Men & 234 & 9,80 & 304 & 12,73 & 76 & 3,18 & 364 & 15,24 & 694 & 29,06 \\
\hline Women & 148 & 6,20 & 202 & 8,46 & 12 & 0,50 & 192 & 8,04 & 162 & 6,78 \\
\hline \multicolumn{11}{|l|}{ Professional status } \\
\hline Farmers & 58 & 2,71 & 62 & 2,90 & 62 & 2,90 & 198 & 9,26 & 44 & 2,06 \\
\hline Employees & 38 & 1,78 & 48 & 2,24 & 4 & 0,19 & 62 & 2,90 & 72 & 3,37 \\
\hline Workers & 10 & 0,47 & 52 & 2,43 & 2 & 0,09 & 88 & 4,11 & 154 & 7,20 \\
\hline Intermediate professions & 14 & 0,65 & 22 & 1,03 & 0 & 0,00 & 14 & 0,65 & 32 & 1,50 \\
\hline Cadres, intellectual or scientific professions & 12 & 0,56 & 32 & 1,50 & 2 & 0,09 & 56 & 2,62 & 76 & 3,55 \\
\hline Artisans, merchants and business leaders & 58 & 2,71 & 106 & 4,96 & 16 & 0,75 & 26 & 1,22 & 170 & 7,95 \\
\hline Without profession & 83 & 3,88 & 178 & 8,32 & 2 & 0,09 & 82 & 3,83 & 204 & 9,54 \\
\hline \multicolumn{11}{|l|}{ Marital status } \\
\hline Married & 242 & 10,13 & 200 & 8,38 & 36 & 1,51 & 324 & 13,57 & 384 & 16,08 \\
\hline Single & 54 & 2,26 & 230 & 9,63 & 24 & 1,01 & 130 & 5,44 & 400 & 16,75 \\
\hline Widow (er) & 36 & 1,51 & 22 & 0,92 & 24 & 1,01 & 60 & 2,51 & 28 & 1,17 \\
\hline Divorced & 50 & 2,09 & 54 & 2,26 & 4 & 0,17 & 42 & 1,76 & 44 & 1,84 \\
\hline \multicolumn{11}{|l|}{ Ethnic group } \\
\hline Adja-Ewe-Mina & 52 & 2,33 & 48 & 2,15 & 8 & 0,36 & 34 & 1,52 & 272 & 12,20 \\
\hline Akposso-Akébou & 10 & 0,45 & 18 & 0,81 & 8 & 0,36 & 34 & 1,52 & 28 & 1,26 \\
\hline Ana-Ife & 10 & 0,45 & 4 & 0,18 & 4 & 0,18 & 140 & 6,28 & 30 & 1,35 \\
\hline Kabyè-Tem & 26 & 1,17 & 340 & 15,25 & 54 & 2,42 & 168 & 7,53 & 384 & 17,22 \\
\hline Paragourma-Akan & 262 & 11,75 & 70 & 3,14 & 18 & 0,81 & 58 & 2,60 & 116 & 5,20 \\
\hline Foreigners & 12 & 0,54 & 12 & 0,54 & 4 & 0,18 & 4 & 0,18 & 2 & 0,09 \\
\hline
\end{tabular}

RS : Region of Savane ; RK : Region of Kara, RC :Central Region ; RP : Region of Plateaux, RM-L : Regions of Maritime and Lomé Commune

\section{Characteristics of alcoholism}

Table 2, shows that in the population, $36.26 \%$ drank occasionally (not more than once per month), 26.12\% moderately (2-4 times per month), weekly $21.39 \%$ ( 2 to 3 times per week) and $16.23 \%$ daily (more than 3 times per week). Whatever the mode of consumption, young people in the 25-34 age group are most affected (38.88\%). According to the results, it is observed that $14.90 \%$ of the subjects consume between 1 and 7 glasses (10 to $70 \mathrm{~g}$ of pure alcohol) of sodabi per week, $9 \%$ drank 8 to 14 glasses (80 to $140 \mathrm{~g}$ of pure alcohol), $8.50 \%$ drank 15 to 21 glasses (150 to $210 \mathrm{~g}$ of pure alcohol) and $5.30 \%$ of the population consuming more than 21 glasses per week. A standard glass of alcoholic beverage at $40 \%$ vol. usually corresponds to $10 \mathrm{~g}$ of pure alcohol (Turner, 1990). The daily average for males is 3 glasses or 30 grams of pure alcohol per day and for women 2 glasses or $20 \mathrm{~g}$ of pure alcohol per day. This consumption level seems high compared to the average daily alcohol consumption reported by Agoudavi et al., (2015) which is $13 \mathrm{~g}$ of pure alcohol for men and $9 \mathrm{~g}$ for women. The WHO report (2014) noted that people in Togo reported a consumption of 1.3 liters of pure alcohol per capita between 2008 and 2014, although in the WHO African region, the average consumption was about $6.0 \mathrm{~L}$ of pure alcohol (13.5 g of pure alcohol per day) per capita. In this study, the 
observed weekly average (20 glasses for men and 14 glasses for women) was in conformity with WHO (in terms of weekly volume, beyond 14 glasses per week for women and 21 glasses for men, there is a risk of excessive drinking, and beyond 48 glasses regardless of sex, there is a risk of alcohol dependence). The same WHO report highlighted a prevalence of harmful alcohol consumption by $12.2 \%$ for men, which is comparable to our findings $(12.0 \%)$ but with a higher sodabi dependence rate of $45.96 \%$ against $5.2 \%$.

In Togo, $34.83 \%$ of the population aged 15 and over, indicate never drinking six or more glasses of sodabi on one occasion and $16 \%$ did so less than once a month over a period of 12 months. In contrast, $20 \%$ of people drank 6 glasses of alcohol or more on one occasion every month, $16.68 \%$ do it every week and $11.49 \%$ almost every day. $49.62 \%$ of drinkers of 6 or more glasses of alcohol come from the Kara Region followed by the Maritime Region and Lomé Commune (42.86\%) and the Plateau Region (4.51\%). The prevalence of sodabi consumption is as follows: $48.58 \%$ (1160 cases) of sodabi drinkers have a consumption risk, $11.26 \%$ (269 cases), harmful consumption and 40.16\% (959 cases) alcohol-dependent. Men consume more sodabi than women, $42.01 \%$ and have a risky consumption, $12.03 \%$ have a harmful consumption and $45.96 \%$ are alcohol-dependent. This difference between men and women seems logical since many surveys show a difference between the sexes (Corrao et al., 2000; 2004). In women, $63.97 \%$ have a risky consumption, $9.50 \%$ harmful consumers and $26.53 \%$ alcohol-dependent. The same observation is made by other studies (Fillmore et al., 1991; WHO, 2014; Agoudavi et al, 2015). Men drink more often than women, regardless of age. They consume alcohol in larger amounts (overall and by occasion) and more often; they are also more often drunk.

Table 2: profiles of alcohol consumption from the survey

\begin{tabular}{|c|c|c|c|c|c|c|c|c|c|c|c|c|}
\hline & $\begin{array}{l}\mathrm{RS} \\
\text { Effec } \\
\text { tive }\end{array}$ & $\%$ & $\begin{array}{l}\text { RK } \\
\text { Effec } \\
\text { tive }\end{array}$ & $\%$ & $\begin{array}{l}\text { RC } \\
\text { Effec } \\
\text { tive }\end{array}$ & $\%$ & $\begin{array}{c}\text { RI } \\
\text { Effec } \\
\text { tive }\end{array}$ & $\%$ & $\begin{array}{l}\text { RM } \\
\text { Effec } \\
\text { tive }\end{array}$ & $\%$ & $\begin{array}{c}\text { Total } \\
\text { Effec } \\
\text { tive }\end{array}$ & $\%$ \\
\hline \multicolumn{13}{|l|}{ Consumption profile for men } \\
\hline \multirow{3}{*}{ Dependence } & & 1,8 & & 7,1 & & 1 , & & 5,6 & & 16 , & & 32 , \\
\hline & 44 & 4 & 170 & 2 & 32 & 34 & 134 & 1 & 388 & 25 & 768 & 17 \\
\hline & & 0,5 & & 2,0 & & 0 & & 2,0 & & 3,1 & & 8,4 \\
\hline \multirow[t]{2}{*}{ Harmful consumption } & 14 & 9 & 48 & 1 & 14 & 59 & 50 & 9 & 75 & 4 & 201 & 2 \\
\hline & & 7,3 & & 3,6 & & 1 & & 7,5 & & 9,7 & & 29 , \\
\hline Risky consumption & 176 & 7 & 86 & 0 & 28 & 17 & 180 & 4 & 232 & 2 & 702 & 41 \\
\hline \multicolumn{13}{|l|}{ Consumption profile for women } \\
\hline \multirow{3}{*}{ Dependence } & & 0,3 & & 4,1 & & 0 & & 0,5 & & 2,5 & & 7,9 \\
\hline & 8 & 4 & 98 & 1 & 10 & 42 & 14 & 9 & 60 & 1 & 190 & 6 \\
\hline & & 0,3 & & 1,1 & & 0 & & 0,6 & & 0,6 & & 2,8 \\
\hline \multirow[t]{2}{*}{ Harmful consumption } & 8 & 4 & 28 & 7 & 0 & 00 & 16 & 7 & 16 & 7 & 68 & 5 \\
\hline & & 5,5 & & 3,1 & & 0 & & 6,7 & & 3,6 & & 19, \\
\hline \multirow{2}{*}{$\begin{array}{c}\text { Risk consumption } \\
\text { Consumption frequency }\end{array}$} & 132 & 3 & 76 & 8 & 2 & 08 & 162 & 9 & 86 & 0 & 458 & 19 \\
\hline & & 6,7 & & 7,8 & & 1, & & 12, & & 8,8 & & 37, \\
\hline \multirow[t]{2}{*}{1 time per month or less } & 158 & 9 & 182 & 2 & 36 & 55 & 280 & 03 & 206 & 5 & 862 & 03 \\
\hline & & 2,4 & & 3,9 & & 1, & & 8,5 & & 10 & & 26 , \\
\hline 2 to 4 times per month & 56 & 1 & 92 & 5 & 28 & 20 & 198 & 1 & 244 & 48 & 618 & 55 \\
\hline 2 to 3 times per week & 104 & 4,4 & 130 & 5,5 & 14 & 0 & 20 & 0,8 & 194 & 8,3 & 462 & 19 , \\
\hline
\end{tabular}


At least 4 times a week

Quantity consumed

1 or 2

3 or 4

5 or 6

7 or 8

10 ou plus

Frequency of consumption of 6 or more glasses

Never

Less than once a month

Once a month

Once a week

Daily or almost

Effects felt

Euphoric effect

Desinhibitor effect

Maintain friendly ties

Anxious effect

Physical dependence

Duration of use sodabi

1 to 5

6 to 10

11 to 15

16 to 20

20 to 25

26 et plus

Consumption of other beverages and noxious substances

Exclusive consumption of sodabi

Beer
Tchoukoutou
Tchakpalo
Lossomissine
Wine

$\begin{array}{cccccccccccc} & 7 & & 8 & & 60 & & 6 & & 3 & & 85 \\ & 1,9 & & 4,3 & & 0, & & 0,6 & & 9,1 & & 16, \\ 46 & 8 & 102 & 8 & 10 & 43 & 16 & 9 & 212 & 1 & 386 & 58 \\ & & & & & & & & & & & \\ & 13, & & 12, & & 0, & & 21, & & 19, & & 67, \\ 328 & 74 & 300 & 56 & 16 & 67 & 522 & 86 & 454 & 01 & 1620 & 84 \\ & 2,0 & & 5,5 & & 2, & & 1,0 & & 12, & & 23, \\ 48 & 1 & 132 & 3 & 52 & 18 & 24 & 1 & 306 & 81 & 562 & 53 \\ & 0,0 & & 1,7 & & 0, & & 0,3 & & 2,7 & & 5,7 \\ 2 & 8 & 42 & 6 & 18 & 75 & 8 & 4 & 66 & 6 & 136 & 0 \\ & 0,0 & & 0,5 & & 0, & & 0,0 & & 0,7 & & 1,4 \\ 0 & 0 & 12 & 0 & 2 & 08 & 2 & 8 & 18 & 5 & 34 & 2 \\ & 0,0 & & 0,8 & & 0, & & 0,1 & & 0,5 & & 1,5 \\ 0 & 0 & 20 & 4 & 0 & 00 & 4 & 7 & 12 & 0 & 36 & 1\end{array}$

$\begin{array}{cccccccccccc} & 12, & & 1,6 & & 0, & & 12, & & 7,5 & & 34, \\ 306 & 93 & 40 & 9 & 12 & 51 & 288 & 17 & 178 & 2 & 824 & 83 \\ & 2,1 & & 3,7 & & 2, & & 1,6 & & 6,8 & & 16, \\ 50 & 1 & 88 & 2 & 48 & 03 & 40 & 9 & 162 & 5 & 388 & 40 \\ & 0,7 & & 4,9 & & 0, & & 7,7 & & 7,2 & & 21, \\ 18 & 6 & 116 & 0 & 10 & 42 & 184 & 8 & 172 & 7 & 500 & 13 \\ & 0,0 & & 5,4 & & 0, & & 0,2 & & 10, & & 16, \\ 0 & 0 & 128 & 1 & 4 & 17 & 6 & 5 & 250 & 57 & 388 & 40 \\ & 0,0 & & 5,5 & & 0, & & 0,5 & & 4,8 & & 11, \\ 0 & 0 & 132 & 8 & 8 & 34 & 12 & 1 & 114 & 2 & 266 & 24 \\ & & & & & & & & & & & \\ & 5,7 & & 5,5 & & 1, & & 16, & & 14, & & 43, \\ 154 & 4 & 148 & 2 & 48 & 79 & 430 & 03 & 380 & 17 & 1160 & 25 \\ & 0,1 & & 2,7 & & 0, & & 0,4 & & 1,7 & & 5,2 \\ 4 & 5 & 74 & 6 & 2 & 07 & 12 & 5 & 48 & 9 & 140 & 2 \\ & 6,1 & & 5,6 & & 0, & & 1,0 & & 6,2 & & 19, \\ 164 & 1 & 152 & 7 & 8 & 30 & 28 & 4 & 168 & 6 & 520 & 39 \\ & 0,4 & & 1,4 & & 0, & & 9,9 & & 2,8 & & 14, \\ 12 & 5 & 38 & 2 & 4 & 15 & 266 & 2 & 76 & 3 & 396 & 77 \\ & 2,0 & & 3,3 & & 0, & & 2,4 & & 8,6 & & 17, \\ 54 & 1 & 90 & 6 & 24 & 89 & 66 & 6 & 232 & 5 & 466 & 38 \\ & & & & & & & & & & & \\ & 10, & & 7,8 & & 2, & & 14, & & 18, & & 52, \\ 240 & 07 & 186 & 0 & 48 & 01 & 342 & 35 & 444 & 62 & 1260 & 85 \\ & 2,4 & & 3,9 & & 1, & & 7,4 & & 13, & & 28, \\ 58 & 3 & 94 & 4 & 28 & 17 & 178 & 7 & 310 & 00 & 668 & 02 \\ & 0,9 & & 3,4 & & 0, & & 1,0 & & 2,7 & & 8,8 \\ 22 & 2 & 82 & 4 & 14 & 59 & 26 & 9 & 66 & 7 & 210 & 1 \\ & 0,8 & & 2,8 & & 0, & & 0,0 & & 1,0 & & 4,8 \\ 20 & 4 & 68 & 5 & 0 & 00 & 2 & 8 & 26 & 9 & 116 & 7 \\ & 1,0 & & 1,9 & & 0, & & 0,2 & & 0,2 & & 3,4 \\ 24 & 1 & 46 & 3 & 0 & 00 & 6 & 5 & 6 & 5 & 82 & 4 \\ & 0,5 & & 1,0 & & 0, & & 0,0 & & 0,2 & & 2,0 \\ 14 & 9 & 26 & 9 & 0 & 00 & 2 & 8 & 6 & 5 & 48 & 1 \\ & & & & & & & & & & & \end{array}$

$\begin{array}{cccccccccccc} & 0,2 & & 1,6 & & 0, & & 0,1 & & 1,8 & & 4,0 \\ 10 & 1 & 80 & 9 & 8 & 17 & 8 & 7 & 86 & 2 & 192 & 6 \\ & 5,5 & & 6,5 & & 0, & & 9,8 & & 14, & & 36, \\ 262 & 4 & 310 & 5 & 36 & 76 & 466 & 5 & 672 & 21 & 1746 & 91 \\ & 0,6 & & 4,9 & & 1, & & 7,5 & & 7,9 & & 22, \\ 32 & 8 & 234 & 5 & 74 & 56 & 358 & 7 & 376 & 5 & 1074 & 71 \\ & 3,2 & & 2,4 & & 0, & & 1,4 & & 3,3 & & 11, \\ 154 & 6 & 114 & 1 & 42 & 89 & 70 & 8 & 158 & 4 & 538 & 37 \\ & 0,2 & & 2,3 & & 0, & & 3,0 & & 3,8 & & 10, \\ 12 & 5 & 110 & 3 & 44 & 93 & 142 & 0 & 180 & 1 & 488 & 32 \\ 72 & 1,5 & 60 & 1,2 & 36 & 0, & 28 & 0,5 & 158 & 3,3 & 354 & 7,4\end{array}$




\begin{tabular}{|c|c|c|c|c|c|c|c|c|c|c|c|c|}
\hline \multirow{4}{*}{$\begin{array}{l}\text { Liquors (wisky, rhum, gin...) } \\
\text { Consumption of other noxious } \\
\text { substances }\end{array}$} & \multicolumn{3}{|c|}{2} & \multirow{2}{*}{$\begin{array}{c}7 \\
1,2\end{array}$} & \multicolumn{2}{|r|}{76} & \multicolumn{2}{|r|}{9} & \multicolumn{2}{|r|}{4} & \multicolumn{2}{|r|}{8} \\
\hline & & 0,2 & & & \multirow[b]{2}{*}{28} & 0 & \multirow[b]{2}{*}{158} & 3,3 & \multirow[b]{2}{*}{82} & 1,7 & \multirow[b]{2}{*}{338} & \multirow{2}{*}{$\begin{array}{c}7,1 \\
5\end{array}$} \\
\hline & 10 & 1 & 60 & 7 & & 59 & & 4 & & 3 & & \\
\hline & & & & & & & & & & & & \\
\hline \multirow[t]{2}{*}{ No } & \multirow[t]{2}{*}{312} & $\begin{array}{l}10 \\
84\end{array}$ & 420 & $\begin{array}{l}14 \\
59\end{array}$ & \multirow[t]{2}{*}{66} & $\begin{array}{l}2, \\
29\end{array}$ & \multirow[t]{2}{*}{510} & $\begin{array}{l}17, \\
72\end{array}$ & \multirow[t]{2}{*}{724} & $\begin{array}{c}25 \\
16\end{array}$ & \multirow[t]{2}{*}{2032} & $\begin{array}{l}70, \\
60\end{array}$ \\
\hline & & 1,0 & & 2,9 & & 0 & & 1,4 & & 21 , & & 27 , \\
\hline \multirow[t]{2}{*}{ Tabacco } & \multirow[t]{2}{*}{30} & 4 & 84 & 2 & \multirow[t]{2}{*}{18} & 63 & \multirow[t]{2}{*}{42} & 6 & \multirow[t]{2}{*}{612} & 26 & \multirow[t]{2}{*}{786} & 31 \\
\hline & & 1,6 & & 0,0 & & 0 & & 0,0 & & 0,0 & & 1,8 \\
\hline \multirow[t]{2}{*}{ Cola } & \multirow[t]{2}{*}{46} & 0 & 0 & 0 & \multirow[t]{2}{*}{8} & 28 & \multirow[t]{2}{*}{0} & 0 & 0 & 0 & \multirow[t]{2}{*}{54} & 8 \\
\hline & & 0,0 & & 0,0 & & 0 & & 0,1 & & 0,0 & & 0,2 \\
\hline Narcotics & 0 & 0 & 0 & 0 & 0 & 00 & 4 & 4 & 2 & 7 & 6 & 1 \\
\hline \multicolumn{13}{|l|}{ Cabarets attendance frequency } \\
\hline \multirow{3}{*}{ Never } & \multirow{3}{*}{24} & 1,0 & & 4,2 & & 0 , & & 10 & & 5,4 & & 21 , \\
\hline & & 9 & 94 & 8 & 4 & 18 & 220 & 02 & 120 & 7 & 462 & 05 \\
\hline & & 7,2 & & 2,2 & & 1 , & & 0,1 & & 5,4 & & 16 , \\
\hline Less than once a month & 158 & 0 & 50 & 8 & 26 & 18 & 4 & 8 & 120 & 7 & 358 & 31 \\
\hline & & 1,2 & & 2,6 & & 0 & & 4,6 & & 5,7 & & 15 , \\
\hline Once a month & 28 & 8 & 58 & 4 & 16 & 73 & 102 & 5 & 126 & 4 & 330 & 03 \\
\hline & & 4,4 & & 4,7 & & 0 , & & 0,5 & & 15 , & & 25 , \\
\hline Once a week & 98 & 6 & 104 & 4 & 8 & 36 & 11 & 0 & 339 & 44 & 560 & 51 \\
\hline & & 1,7 & & 7,4 & & 0 , & & 0,3 & & 11 , & & 22 , \\
\hline Daily or almost & 38 & 3 & 164 & 7 & 18 & 82 & 7 & 2 & 258 & 75 & 485 & 10 \\
\hline
\end{tabular}

RS : Region of Savane ; RK : Region of Kara, RC : Central Region ; RP : Region of Plateaux, RM-L : Maritime Region and Lomé Commune

In total, $51.40 \%$ of the study population abusively consume sodabi, $40.59 \%$ for men against $10.81 \%$ for women. This sodabi abuse affects men and women in the Maritime region and Lomé Commune $(47.78 \%$ and $29.46 \%)$ and the Kara region (22.50\% and $48.84 \%)$. The STEPS survey in Togo (2010) noted that the highest prevalence in harmful alcohol consumption was observed in the Kara (6.2\%), Savana (5.3\%) and Central regions (4.2\%). An understanding of this type of alcoholism could be related to cultural causes, geographical and financial accessibility and a return to traditional values (Yeo-Tenena et al., 2006). It is therefore not surprising to find this high proportion, because in targeting the consumer of sodabi one unintentionally selects the ethnic group (Adja-Ewe-Mina) that populates the region and who have made sodabi their preference. Environmental factors such as economic development, culture, the availability of alcohol and the effectiveness of policies on the consumption of alcohol, are relevant factors that explain differences in vulnerability between societies, historical trends of alcohol consumption and alcohol-related harm (Babor et al., 2010; Nelson et al., 2013). Young people in the 25-34 age range (19.46\%) consume sodabi more abusively (harmful use and alcohol dependence) than other drinkers in the nation. This presentation of proportions appears to be consistent with distributions usually obtained in Europe and America where the highest frequency of alcohol abuse is found among young adults (Hibell et al., 2004). Similarly, in the population studied, younger drinkers aged 15-34 have the highest risk behaviors $(8.51 \%$ non-harmful use; $1.6 \%$ of harmful 
drinking and 5.05\% of alcohol-dependent) than people aged over $64(0.51 \%$ non-harmful use, harmful use of $0.16 \%$ and $0.59 \%$ of alcohol-dependent). The prevalence of excessive and repetitive drinking also varies with age and between 18-24 years, it reached a peak, while the lowest level was observed at age 65 and over (Éduc'alcool, 2005 ). Therefore the overall trend shows a decline in consumption of alcohol by subjects with age: they drink more frequently but the quantities consumed are smaller, especially among men (Assanangkornchai et al., 2000). The prevalence of excessive consumption of sodabi is higher among the unemployed (12.35\%) than other professions: farmers $(9.93 \%)$, manual workers $(8.76 \%)$, craftsmen, traders and business leaders $(8.68 \%)$, employees $(6.34 \%)$, managers $(3.26 \%)$ and intermediate professions $(1.75 \%)$. The high consumption rate of sodabi by the unemployed, peasants and farmers may be related to the fact that these socioprofessional categories of the population do not have the necessary economic resources and give themselves to alcoholism easily. Indeed, as shown by Gruenewald et al., (2006), the change in youth behavior in the face of increases in the price of industrially produced alcohol is evident. Price increases may result in consumers reducing their overall consumption or substituting with other cheaper drinks (OMS, 2006). The unemployed were 2.4 times more likely to suffer from alcohol dependence than those who exercise a professional activity (Anthony et al., 1994). According to Agoudavi et al., (2015), those with a fragile socioeconomic status, appear to be more vulnerable to the problems and consequences of alcoholism. This study has also found that some sodabi consumers $(36.91 \%)$ drink also beers, more precisely craft beers such as tchoukoutou, tchakpalo and Lossomissine which are different types of sorghum beer in Togo. Thus, $22.71 \%$ of subjects are interested in tchoukoutou, $11.37 \%$ in tchakpalo and $10.32 \%$ in Lossomissine. As for the beers, which are the first to be excessively consumed whatever the group criteria considered, they employ the most attractive and aggressive marketing actions (Yao et al., 2015). Among the excessive consumers of alcohol, there are two times more men $(58 \%)$ than women $(36 \%)(\mathrm{RR}=1.61)$, a thesis confirmed by Kairouz et al., (2008). The prevalence of excessive consumption is similar among subjects living alone or as couples $(\mathrm{RR}=1.21)$. In contrast, for authors such as Com-Ruellele et al., (2008), the risk of excessive drinking is especially concentrated among single people, men or women. The prevalence of harmful alcohol consumption was higher among married and divorced participants as reported by Agoudavi et al., (2015).

Among consumers of excess alcohol, the risk is identical regardless of the professional category $(\mathrm{RR}=1.13)$. The majority of respondents $(81.48 \%)$ consumed sodabi for less than ten years. In the 35-44 age group, $6.57 \%$ consumed sodabi for over ten years. Traditional alcoholic beverages 
represent a hidden dimension of the problems related to alcohol consumption in many developing countries. The use or abuse of alcohol among drinkers is usually accompanied by other types of risky behavior such as smoking. $84.81 \%$ of the drinkers said they had not used other harmful substances; $12.69 \%$ use tobacco; $2.25 \%$ eat cola and $0.25 \%$ of drinkers take other drugs. $21.05 \%$ of drinkers have never frequented drinking establishments but $25.51 \%$ visited drinking establishments once a week and $22.10 \%$ almost every day. $87.54 \%$ of drinkers in the Maritime Region and Lomé Commune visited drinking establishments. The euphoric effect of alcohol (45.23\%) and the consolidation of friendly ties $(19.39 \%)$ brought about by visits to drinking establishments was about $64.62 \%$. These desired effects explain the presence of sodabi at all ceremonial occasions. Indeed, the euphoric and comforting effects aside, alcohol facilitates human relations and promotes adjustment to the group (Yeo-Tenena et al., 2006). Alcohol abuse is also associated with a range of social problems, as well as physical and mental disorders, including depression and anxiety, obesity and risk of accidents (Currie et al. 2010). When it comes to home brew, it's not without some degree of risks of the occurrence of methanol in the resulting beverages. Methanol also known as wood alcohol is highly toxic to the human body, and its consumption can lead to serious consequences such as blindness and even death. Studies have shown that the first stillage that comes out of a still during the production of sodabi, is often loaded with methanol and must be thrown out. Besides, there are some dangers of methanol poisoning from the ingestion of adulterated sodabi laced with methanol by unlicensed brewers in order to increase the alcoholic content. Fortunately it was found in the sodabi in question only traces of methanol at doses that pose no serious risk of toxicity on consumption. Methanol occurs naturally in fruits and vegetables (World Health Organization, 1997). The production of free methanol in all these instances is the result of hydrolysis of methylesters in pectin, which will break down to methanol when the plant cell walls and middle lamellae are disrupted, as can happen through physical processes of food preparation (Anthon and Barrett, 2010). In this study, among the damage caused by sodabi abuse, $39.26 \%$ of complications are somatic damage or neurological disorders such as decreased libido (2.6\%), fatigue (8.89\%), sweat (13.98\%), tremor $(4.93 \%)$, fatigue and pain $(4.66 \%)$. Sodabi is a risk factor that can lead to cardiovascular disease $(0.87 \%$ of the cases in our study), a thesis supported by Corrao et al. (2000) who claim that alcohol increases cardiovascular disease. $60.74 \%$ of all other damages mentioned by drinkers are psychological and psychiatric complications. Among the most important complications are agitations (12.75\%), loss of self-control (10.92\%); incoherent and slurred speech $(10.51 \%)$; attention deficit $(8.54 \%)$, insomnia $(6.62 \%)$, personality disorder $(5.76 \%)$ and depression (1.96\%). Alcohol 
consumption is associated with many other neuropsychiatric disorders, such as depression or anxiety disorders (Kessler, 2004; Boden and Fergusson, 2011). The results, supported by numerous studies, show that depressed individuals with mood disorders are at high risk of alcohol dependence and vice versa (Regier et al., 1990).

In the African Region, the disease burden due to neuropsychiatric disorders and unintentional injuries attributable to alcohol is high among both men and women 2002). This is the first study on sodabi consumption in Togo. The objective is to help guide prevention efforts to reduce prevalence.

\section{Conclusion}

The study showed that consumption of sodabi is not evenly distributed in the population of Togo. Sodabi consumption is more popular in the Maritime region and the Lomé Commune, in the Kara region and especially in the Central Region. The differences in consumption in the population are related to the level of development of their environment, their financial means and the availability of alcohol products. Sodabi is widespread and appreciated, and it is difficult to have the perspective and objectivity to realize its problems and deal with them. Men, more than women, consumed sodabi abusively. The fact of having consumed alcohol in the past year changes with age and abusive consumption is more important from age 25. Meanwhile, information campaigns must take into account the quantities of alcohol consumed, and consumption patterns in different regions of the country, because, although alcohol often has connotations of pleasure and sociability, its adverse consequences are very diverse. Moreover, technical assistance for the production of this alcohol would allow to identify the various quality problems in sodabi production.

\section{Acknowledgements}

We are grateful to the General practitioners, the medical students, the laboratory assistants and drinking places managers and sodabi outlets in the regions of Togo and all those who participated in this study.

\section{References:}

Agoudavi K., Dalmay F., Legleyle S., Kumako K., Preux, PM.. Clément J.P, Falissard, B.Nubukpo P. (2015). Epidemiology of alcohol use in the general population of Togo. Addictive Behaviors Reports 2 (2015) 1-5

Anthon GE. and Barrett DM. (2010). Changes in pectin methylesterification and accumulation of methanol during production of diced tomatoes. Journal of Food Engineering 97:367-372. 
Anthony JC., Warner LA., et Kessler RC. (1994). Comparative epidemiology of dependence on tobacco, alcohol, controlled substances, and inhalants : basic findings from the national comorbidity survey. Exp and clin in psychopharmacology 2 : 244-268.

Assanangkornchai S., Saunders JB., Conigrave KM. (2000). Patterns of drinking in Thaimen. Alcohol Alcohol, 35 : 263-269.

Babor T., Caetano R., Casswell S., Edwards G., Giesbrecht N., Graham K. Grube J.W., Hill L., Holder H., Homel R., Livingston M., Österberg E., Rehm J., Room R. et Rossow I. (2010). Alcohol: No Ordinary CommodityResearch and Public Policy. Oxford, UK: Oxford University Press.

Boden JM., Fergusson DM. (2011). Alcohol and depression. Addiction. 106:906-14.

Com-Ruelle L., Dourgnon P., Jusot F. et Lengagne P. (2008). Facteurs socio économiques associés à la consommation d'alcool en France : une étude des différents modes de consommations. Institut de recherche et documentation en économie de la santé (Irdes), Paris, France ; b Université Paris-Dauphine, Paris, France.

Corrao G., Rubiati L., Bagnrdi V., Zambon A, Poikolainen K. (2000). Alcohol and coronary heart disease: a meta analysis. Addiction, 95: 15051523.

Corrao G, Bagnardi V, Zambon A, La Vecchia C. (2004). A meta analyse of alcohol consumption and the risk of 15 diseases. Prev Med, 38: 613-619.

Currie C., Zanotti C., Morgan A., Currie D., De Looze M., Roberts C., Samdal O., Smith ORF., Barnekow V. (2010). Social determinants of health and well-being among young people. Health Behaviour in School-aged Children (HBSC) study: international report from the 2009/2010 survey. WHO Regional Office for Europe, Copenhague Health Policy for Children and Adolescents, No $6 ; 252 \mathrm{p}$.

Éduc'alcool. (2005). Alcool et santé. Les effets de la consommation modérée et régulière d'alcool, Montréal, Éduc'alcool, 14 p.

Fillmore KM., Hartka E., Johnstone BM., Leino EV., Motoyoshi M., Temple MT. (1991). A Meta-analysis of life course variation in drinking. $\mathrm{Br} J$ Addict, 86 : 1221-1267

Gache P., Michaud P., Landry U., Accietto C., Arfaoui S., Wenger O., Daeppen JB. (2005). The Alcohol Use Disorders Identification Test (AUDIT) as a screening tool for excessive drinking in primary care: reliability and validity of a French version. Alcohol Clin Exp Res. ; 29(11):2001-7.

Goeh-Akue E., Yehadji KY., Baragou S., Ekoue-Kouvahey 0., Assou K., Soussou BL. (2008). Hypertension artérielle en milieu rural au Togo: cas du Distrct Sanitaire d'Agou. Rev. CAMES - Série A,Vol. 06. 
Gruenewald PJ., Ponicki WR., Holder HD., Romelsjö A. (2006). Alcohol prices, beverage quality, and the demand for, alcohol: quality substitutions and price elasticities. Alcoholism: Clinical and Experimental Research, 30: 96-105.

Hibell B., Andersson B., Bjarnason T., Ahlström S., Balakireva O, Kokkevi A., Morgan M. (2004). The ESPAD report 2003: alcohol and other drug use among students in 35 European countries. Stockholm, Swedish Council for Information on Alcohol and Other Drugs: 457p.

Kairouz S., Boyer R., Nadeau L., Perreault M. et Fiset-Laniel J. (2008). Troubles mentaux, toxicomanies et autres problèmes liés à la santé mentale chez les adultes québécois. Enquête sur la santé dans les collectivités canadiennes (cycle 1.2), Québec, Institut de la statistique du Québec, 67 p.

Kessler RC. (2004). The epidemiology of dual diagnosis. Biol Psychiatr. 56:730-7.

Lim SS, Vos T, Flaxman AD, Danaei G, Shibuya K, Adair-Rohani H. (2012). A comparative risk assessment of burden of disease and injury attributable to 67 risk factors and risk factor clusters in 21 regions, 19902010: a systematic analysis for the Global Burden of Disease Study 2010. Lancet. 380:2224-60. doi:10.1016/ S0140-6736(12)61766-8 [PMID:
[P 23245609].

McGovern P. (2009). Uncorking the past: The quest for wine, beer, and other alcoholic beverages. Berkley (CA): University of California Press.

Nelson DE, Jarman DW, Rehm J, Greenfield TK, Rey G et Kerr WC. (2013). Alcohol-attributable cancer deaths and years of potential life lost in the United States. Am J Public Health. 641-8. doi: 10.2105/ AJPH.2012.301199.

OMS (Organisation Mondiale de la Santé). (2006). OMS Comité d'experts des problèmes liés à la consommation d'alcool. Genève, Suisse Série de rapports techniques, deuxième rapport; no. 944, 76 p.

OMS. (2002). Charge de morbidité mondiale et régionale attribuable à la consommation d'alcool, Organisation mondiale de la Santé.

Rapport final de l'enquête STEPS TOGO 2010 (2010STEPS_Report_TOGO_FR.pdf)

Regier, DA., Farmer, ME., Rae, DS. (1990). Comorbidity of mental disorders with alcohol and other drug abuse: Results from the Epidemiologic Catchment Area (ECA) study. JAMA: Journal of the American Medical Association, 264, 2511.2518.

Schwartz D. (1969). Méthodes statistiques à l'usage des médecins et biologistes, édition Flammarion Médecins Sciences, 1969

Turner C. (1990). How much alcohol is in a "standard drink": an analysis of 125 studies. British Journal of Addiction, 85, 1171-6. 
Willis J. (2006). Drinking crisis: Change and continuity in cultures of drinking in sub-Saharan Africa. Afr J Drug Alcohol Studies. 5:1-15. World Health Organization (2014). Global status report on alcohol and health. Geneva: World Health Organization.

(http://www.who.int/substance abuse/publications/global_alcohol_report/en/) World Health Organization. (1992). WHO Statistical Classification of Diseases and Related Health Problems (ICD) 10th revision. Geneva.

World Health Organization (1997). Environmental Health Criteria 196 Methanol. International Programme for Chemical Safety, World Health Organization, Geneva. ISBN 9241571969.

World Health Organization (2010). Global Strategy to reduce the harmful use of alcohol 2010.2 Geneva (http://www.who.int/substance_abuse/msbalcstragegy.pdf Yao KM., Badjo PC., Assi BD., Adou KF.J-B. Bâ A., Glin L., Camara PA., Tako NA. et Seri B. (2015). Evaluation des consommations excessives d'alcool (binge drinking) en Côte d'Ivoire : cas de la ville d'Abidjan. Int. $J$. Biol. Chem. Sci. 9(3): 1209-1219

Yeo-Tenena YJ., Yao YP., Konan OYE., Koffi KE., Amani N., Delfosse RCJ. (2006). Enquête épidémiologique à propos des usagers des débits de boissons traditionnelles (Bandjidromes d'Abidjan et de sa banlieue) Med Trop 2006; $67: 53-5$ 